\title{
Obituary - Boris Yakovlevich Kaplan
}

\author{
Yulia Sister ${ }^{1}$
}

Received: 30 August 2017 / Accepted: 31 August 2017 /Published online: 22 September 2017

(C) Springer-Verlag GmbH Germany 2017

Boris Yakovlevich Kaplan

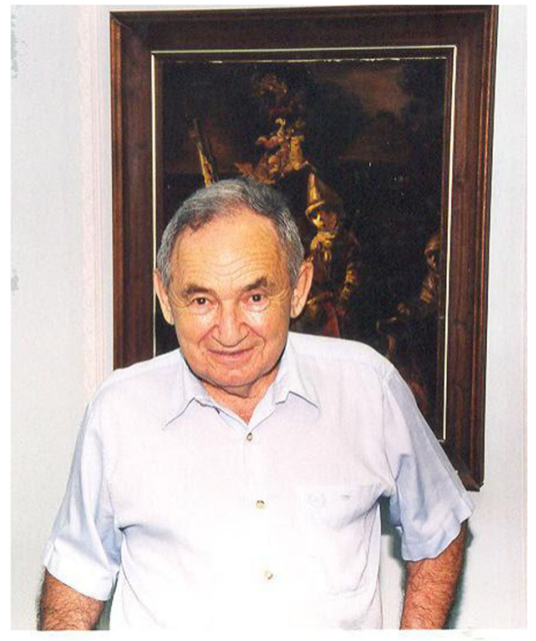

Colleagues and friends mourn the passing of Boris Yakovlevich Kaplan on July 28, 2017. Boris (Borukh) Yakovlevich was a famous scientist, doctor of science (highest degree in science in USSR/Russia), professor, and corresponding member of the Russian Academy of Sciences.

Boris Yakovlevich was born on March 12, 1922 in Białystok, Poland. In 1939, he finished the Hebrew Gymnasium in Białystok, short before its destruction by the invading Germans. This school, established in 1919, was a

Translated from Russian by Fritz Scholz

Yulia Sister

ysister914@gmail.com

1 Scientific Research Center "Russkoe yevreystvo v zarubezhye" ("Russian Jewry Abroad") POB 6464, 76920 Kiryat Ekron, Israel
Zionist foundation to prepare students for Israel. Boris Yakovlevich was accepted at the Chemistry Faculty of the Jerusalem University, but he could not travel to Jerusalem because of the outbreak of World War II. So he started at the Chemical Faculty of the University of Lvov (now Lviv, Ukraine) where he finished the first course. Lvov became part of the Soviet Republic of Ukraine in 1939, when the Soviet Army invaded the Eastern parts of Poland. In October 1941, Boris Yakovlevich volunteered for the Soviet Army and served almost all the war years. In 1945, he was seriously injured, and a leg had to be amputated. He has been decorated with the Order of the Patriotic War, 1st class ('Red Star') and others.

After demobilisation in September 1945, Boris Yakovlevich joined the second course of the Chemical Faculty of the Moscow State University where he graduated with honours in 1949. From 1950 to 1960 , he headed the methodological group of the Central Chemical Laboratory of Geology of the Central Districts. After that, he worked until 1992 at the State Institute of Rare Metals (GIREDMET) in Moscow as senior scientist and head of a division.

Boris Yakovlevich made fundamental contributions to the development of analytical chemistry, especially to the theory and application of alternating current and pulse polarography, and to the determination of kinetic constants of electrode reactions on the basis of polarography and direct and reverse relaxation techniques. Among his many contributions, the following may be mentioned: optimisation of differential pule analyses, determination of various metals in ores, and of sulphur, selenium, rare earth elements, carbon, nitrogen, arsenic, and impurities in semiconductors.

Boris Yakovlevich was a member of the Scientific Council of the Academy of Science, head of the Commission for Metrology and Terminology, and author of a number of technical standards concerning general questions of analytical 
quality control. His more than 250 scientific publications include the well-known monograph "Impul'snaya polyarografiya" ("Pulse polarography"), Moscow, Kimiya 1978, "Vol'tampreometriya peremennogo toka" ("AC voltammetry"), Moscow, Khimiya 1984, and "Metrologiya analiticheskogo kontrolya proizvodstva v cvetnoy metallurgii" ("Metrological control of production in nonferrous metallurgy") Moscow, GIREDMET, 1984, and Moscow, Metallurgiya, 1989.

Boris Yakovlevich excelled in knowledge, erudition, human kindness, and helpfulness.

In 1992, he repatriated with his family to Israel. Here, he met old friends and relatives from Poland who have survived the war. He did not know that they have survived, and they thought that he has been killed in action. Since his Gymnasium, he commanded literary Hebrew, and so he enjoyed speaking with them in Hebrew, the language in which he read a lot. In Israel, he joined the Union of Disabled War Veterans.

Boris Yakovlevich will stay in our hearts and in the works of new generations of chemists.

We mourn with his family.

Blessed be the memory of him!

Dr. Yulia Sister (Rehovot), Prof. Victor Mairanovsky (Berlin), Dr. Efim Rosenblat (Donetsk), Dr. Victor Gleser (Ashdod), Dr. El'za Zakharova (Tomsk), Dr. Tasya Ivcher (Haifa), Dr. Rimma Lyalikova (Baltimore), Prof. Anna Brainina (Yekaterinburg), Prof. Yakov Turyan (Newton), Dr. Iva Turyan (Newton), Prof. German Budnikov (Kazan), Prof. Valeriy Maystrenko (Ufa), Dr. Larisa Kopanskaya (Kishinëv), Dr. Vladlena Khomenko (Kishinëv), and others. 